\title{
Educative Values of Peace Mind Mysticism of SunanBonang In the view of Islam
}

\author{
Fatchullah Zarkasia, 1 \\ aniversitas Gunadarma, Indonesia \\ 'fatchullahzarkasi@gmail.com
}

\begin{abstract}
The majority of Javanese which many called "abangan" has its own perspective on the major religions in the world. For Niels Mulder in his book, the Javanese tend to view Islam as a religion is Arab, so that Islam seemed to fizzle placed as the basis of life for the Javanese belief. However, virtually no Muslims in Indonesia who have never heard the name WaliSongo, collective unit 9 guardian. SunanKalijaga better known than all eight other guardians with various famous work. Puppet world is said to be the work of these guardians, as sekaten, which has been called, is a tradition of the Prophet's birth day celebration that is celebrated officially the Kingdom of Yogyakarta and Surakarta, until today. Sidi Gazalbarevealed that: "Value is something that is abstract. Value is not a concrete object, not a fact, not just a question of right and wrong that demands empirical evidence, but rather a matter of appreciation that is desired, liked and disliked.While Educative education comes from the word that means pendidikan.Sedangkan education question in this case is the Islamic education. So according to Prof. Dr. Omar M. Taomy al PendidikaanSyaibany in his philosophy of Islam, it can be concluded that: "Islamic Education is an attempt to change the behavior of individuals in the life of their community and also in the surrounding environment through the education process. The changes are based on the values of Islam."
\end{abstract}

Keywords:

Mysticism; Values; Educative; SunanBonang

This is an open access article under the CC-BY-NC license

\section{INTRODUCTION}

Suluk as Sufism patterned bouquet delivered in the form of song, has a major influence on the spiritual life of society Jawa.Sebab contained therein many piwulang processing or spiritual soul of man to achieve perfection. This was done through communication with the Almighty God in unity and readiness of the soul. On the other hand the emergence of this great influence because the relationship between the Java community with the mysticism literature so closely that creates a tribal identity that they are proud of. Denying the role of literary mysticism is to deny the reality of Javanese culture. $^{1}$

The majority of Indonesia's population is Javanese with distinctive traditions, like other communities, which gives a distinctive color pattern development of understanding and practice of Islam in this country. Typical Javanese Islam was often called Islam kejawen, kebathinan, or abangan. ${ }^{2}$

${ }^{1}$ HaqZaairul, SulukKatentraman Soul SunanBonang, (Bantul: Media Insani, May 2012,) h.73

${ }^{2}$ Abdul Munir Mulkhan, bird of paradise and science Makrifatkasampurnan sheikh Siti jenar ... h. 108 
The majority of Javanese which many called "abangan" has its own perspective on the major religions in the world. For NielsMulder in his book, the Javanese tend to view Islam as a religion is Arab, so Islamtampak failed placed as the basis of life for the Javanese belief. However, virtually no Muslims in Indonesia who have never heard the name WaliSongo, collective unit 9 guardian. SunanKalijaga better known than all eight other guardians with various famous work ${ }^{3}$.Dunia puppet said to be the brainchild waliini, as sekaten, which has been called, is a tradition of the Prophet's birth day celebration that is celebrated officially the Kingdom of Yogyakarta and Surakarta, until today.

Ornaments puppet, for example, is believed to depict the monotheistic belief, Allah and Muhammad's letter as well as the shahada. Puppet is the most popular folk art. In it reflected belief systems and rituals in the life of Javanese people who have already lived. The same thing is also reflected in the gamelan drumming used the trustees as a means to call on people to come to the mosque to listen to the story of the birth of Prophet Muhammad. Puppet, sekaten, gerebeg, selametan, and various forms of the mosque, is one form of which may be commonly referred to syncretic, as the result of a process of dialogue Islam and local traditions are long ${ }^{4}$,

\footnotetext{
${ }^{3}$ Abdul Munir Mulkhan, bird of paradise and science Makrifatkasampurnan sheikh Siti jenar ...h. 106

${ }^{4}$ Abdul Munir Mulkhan, bird of paradise and science Makrifatkasampurnan sheikh Siti jenar ...h. 130
}

Sheikh Ali Mahfouz stated, if you want to follow the example of the Prophet, the call must be nurtured four fundamental basis, namely:

1. Al HujjajBalagha (a good reason)

2. Al asalibulHakimah (wording filled wisdom)

3. Al adabussamiyah (courtesy or good manners and noble).

\section{As SiyatulHakimah (tactics wise) ${ }^{5}$}

SunanKalijaga proposed that the customs of Java such as salvation, bersaji and others not directly challenged because the Javanese people will flee if menjahui scholars strongly opposed. It is proposed that the customs of color or element on a proposal Islam.SunanAmpelSunanKalijaga ask it. "Is it customary long -Istiadat will not worrisome when considered in Islam? And that should not exist in Islam ${ }^{6}$, Does not this would be heresy? "

SunanAmpel question is answered by Sunan Kudus.

"I agree with SunanKalijaga, because there are some Buddhism similar to the teachings of Islam, that the rich should help the poor and the concerns Kanjengmiskin.AdapunSunanAmpel, I have faith that later on there will be Muslims who will improve . "

Supporters SunanKalijaga five people, while supporters of SunanAmpel support only two people SunanGiri and SunanDrajat, the proposal received

\footnotetext{
${ }^{5}$ HaqZaairul,

SulukKatentramanSunanBonang soul ... h. 67

${ }^{6}$ AR. MB. Rahimsyah, Story Walisongo

(Surabaya: Human Settlements, 2011,) ... h.93
} 
SunanKalijaga. Colored Javanese customs of Islam, among others, salvation, mitoni, salvation send prayers for the dead (usually called tahlilan) and others that are essentially not contrary to Islamic faith.

In suatau when the trustees gathered after forty days of the death of SunanKalijagaAmpel.Sunan suddenly burning incense. The trustees others consider SunanKalijaga action is too excessive for burning incense is a habit people are un-Islamic Javanese. $^{7}$

Sunan Kudus said, "Burn this incense is usually done by the Javanese to summon the spirits of the mati.Ini not exist in Islam."

SunanKalijaga said, "We are going to invite the Javanese conversion to Islam, we should be able to approach the burning incense them.We not to call the spirits of the dead, but merely scent a room, because people mostly only know Java incense as a fragrance, not fragrant perfume lainnya.Bukankah it disunnatkan Prophet? "

"But it does not have to burn incense!" Said Sunan Kudus. ${ }^{8}$

"Is there anything in the hadith mentioned ban burning incense as pemgharum room?" Answer SunanKalijaga.

Other guardians only silence. While the actual Sunan Kudus more inclined to side with

$$
\text { h.93 }{ }^{8} \text { AR. MB. Rahimsyah, Story Walisongo ... }
$$$$
{ }^{7} \text { AR. MB. Rahimsyah, Story Walisongo ... }
$$

SunanKalijaga this time somehow-feel uncomfortable on actions SunanKalijaga.

SunanKalijaga really like weird, "said Sunan Kudus. "But do not debase SunanKalijaga as a guardian to wear clothes like that." SunanKalijaga is more often dressed as ordinary people. Long pants and a black or blue shirt with the same color, just a udeng headband or headband.

SunanKalijaga answered, "Before God nothing special. Only the levels of taqwa as measure the degree of a person. Similarly pakaian.Lagi not only the obligations of an Islamic teaching his people shut aurat.Tidak any mention must wear jubbah or sarung.Justru dressed like this I can get along with commoners and I could easily give the teachings of Islam to them. "

Return the trustees confirmed the opinion of SunanKalijaga.

Furthermore SunanKalijaga also proposed that folk arts like the musical, songs and puppet can be accepted by the trustees as dakwah.Usul media is also by the mayor finally disetujui.Demikianlah a little story Walisongo teachings of SunanKalijaga and SunanBonang. ${ }^{9}$

Based on the description above and the reality that has been especially around people of Indonesia, Java, the authors are encouraged to conduct a study of Scientific then the authors propose the title of this proposal is that the author gave the title "Educative Values of Peace Mind Mysticism of SunanBonang In the view of Islam".

\footnotetext{
${ }^{9}$ AR. MB. Rahimsyah, Story Walisongo ...
} 
In the book of Al Arba'in fi usul al din said that perfect happiness is happiness that includes two dimensions, ie the dimensions of the world and the hereafter dimensions. Happiness in the world can be felt with a peaceful soul. Happiness in the hereafter is happiness to meet and communicate with God (Ahmad FaizurRosyad, Pole: 2004) ${ }^{10}$, In Man's search for Meaning, Dr. Viktor E. Frankl, Professor of Mental Diseases at the University of Vienna wrote, "human search for meaning of life is a major force in his life and not a secondary rationalization of movement instinct" (J. Maurus, Love Pena: 2005). Happiness and peace of mind really is not as simple as we thought. Why is that ? For to achieve it required a series of business any time always consider the needs, risks and value of taste that is created. Even the natural potential that we have as a psychic and organs - organs of our body, also take into consideration. ${ }^{11}$

\section{THEORETICAL PERSPECTIVES}

Definition of Value

Sidi Gazalba revealed that: "Value is something that is abstract. Value is not a concrete object, not a fact, not just a question of right and wrong that demands empirical evidence, but rather a matter of appreciation that is desired, liked and disliked. ${ }^{12}$

SunanBonang ... h.73

$$
{ }^{11} \text { HaqZaairul, SulukKatentraman Soul }
$$
SunanBonang ... h.74

${ }^{12}$ ChabibToha, et.al., reformulated Philosophy of Islamic Education (Yogyakarta: Student Library, 1996), p. 22.
According to Milton Rokeach and James Banks, the value is a type of confidence that is within the scope of the belief system in which a person acts or something inappropriate about dikerjakan.Nilai indicates a criterion or standard to judge or evaluate something as good industrialization is a means of prosperity, understanding there are various types of individual values, social, cultural and religious. ${ }^{13}$

Educative

Educational is an adjective (object) that is derived from the word educate (educate) means to provide an increase (to elicit, to give rise to), and develop (to evolve, to develop). In a narrow sense, education or training means the act or process of acquiring knowledge act (McLeod, 1989). Furthermore, the definition of "education" according to Indonesian Dictionary is the process of changing attitudes and procedures of behavior or groups of people in human mature business through teaching and training efforts. ${ }^{14}$ While education is referred to in this case is the Islamic education. According to Prof. Dr. Omar M. Taomy al PendidikaanSyaibany in his philosophy of Islam, he said: "Pendidikaan Islam is an attempt to change the behavior of individuals in the life of their community and also in the surrounding environment through the education

\footnotetext{
${ }^{13}$ ChabibToha, Capita Selecta Islamic Education, p. 60-61.

${ }^{14}$ Muhibbin Shah, Educational Psychology, (Bandung: PT Youth Rosdakarya, 2013), p 10
} 
process. The changes are based on the values of Islam ". ${ }^{15}$

So it is educational values is an educational process in which there are values of human change for the better.

\section{RESULT AND DISCUSSION}

\section{Understanding about Peace Mind Myticsm}

In the Hadith The Prophet

حد ثنا محمو د بن غيلان, أ خبرنا أبو أ

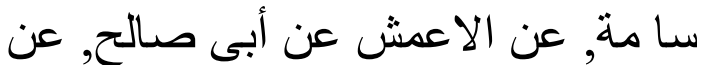

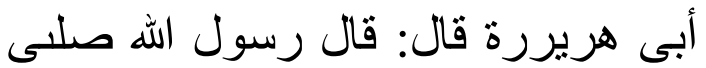

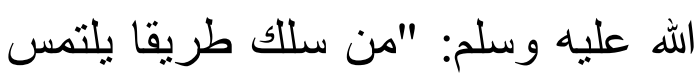

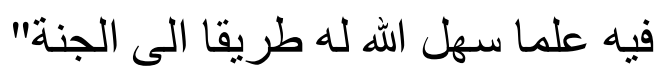

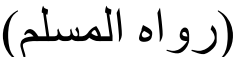

Mahmud bin Ghailan told us, Abu Osama

told us, from Al-A'masy of Abi Salih, from

Abu Hurairah says: Rasulullah SAW said:

"Whoever goes in search of knowledge,

Allah will make easy for him the way to

Heaven". (H. R Muslim) ${ }^{16}$
The word comes from the root word Suluk Salaka yasluku sulukan ( سلك يسلك سلكا) From a fragment of a word in the Hadith The Prophet includes the word "Salaka" which was interpreted by commentators agreement is "running", while in another interpretation, namely Suluk: Sufism patterned bouquet delivered in the form of song, has a major influence on the spiritual life of the Java community. For therein is contained piwulang processing or spiritual soul of man to achieve perfection ${ }^{17}$, So sulukkatentraman soul "Tomboati" is a literary creation which SunanBonang in this song contains righteous deeds that are useful for improving heart sick. This means that the song is a masterpiece TomboAtiWalisongo that reflect their propaganda methods in spreading Islam in the archipelago, especially the island of Java. ${ }^{18 T o m b o A t i}$ song is just one of the many works that aims to provide a living for the Muslims who are still "old corn" at the time.

In the history say, in Java, Islamic law starts in earnest is when the reign of the kingdom of Demak, the first king Raden Patah. According to the humanist WS. Renda in an oration mention that Megatruh, "Salokantara" that are composed by King Jayalengkara and "Jugul Young" are from the statute books Demak obviously has the foundation of Islamic

\footnotetext{
${ }^{17}$ HaqZaairul, SulukKatentraman Soul SunanBonang ... h.73

${ }^{18}$ HaqZaairul, SulukKatentraman Soul SunanBonang) ... h.59
} 
law. ${ }^{19}$ And Walisanga as central scholars when it plays a very important role even used to say beyond the King of Demak. Because they are regarded as the elder person, referenced the Islamic sciences, and guardians of God who have achieved a high maqam. ${ }^{20}$

In other words conceptually SunanBonang own propaganda methods and other Walisanga also commonly referred to as 'want' idzatulhasanahwa hiya Mujadalahbillatiahsan ". This method is commonly used for the character -

Special characters, such as kings, nobles, rich people, landlords, and local community leaders. ${ }^{21}$

On the other hand, the purpose of his mission seems also to help the community problems associated with the "defilement of the soul". Given that the community faced at that time he was a damaged society. Felon, robber, robbers, murderers roam everywhere, and automatically, healthy life is an expensive item that not everyone can afford to have it. Or at least, the threat of getting it are very severe and difficult to avoid. From it certainly needed a surefire formula to deal with the crisis this tranquility. ${ }^{22}$

Actually, the various forms of consideration that he did this, also can not be said to have separated

\footnotetext{
${ }^{19}$ HaqZaairul, SulukKatentraman Soul SunanBonang ... h.60

${ }^{20}$ HaqZaairul, SulukKatentraman Soul SunanBonang ... h.60

${ }^{21}$ HaqZaairul, SulukKatentraman Soul SunanBonang ... h. 61

${ }^{22}$ HaqZaairul, SulukKatentraman Soul SunanBonang ... h. 63
}

entirely from the political content. Because basically all of it focused on two basic objectives he now is finding support in order to maintain and develop the existing kingdom of Demak Islam and to spread the religion of Islam itself to all corners of the land of Java. Even so, it is necessary to be recognized that the propagation of Islam conducted by SunanBonang and Walisanga was superb. The guardian was very skilled in designing propaganda that want to say to the Java community by using various means of media propaganda. And we should be proud of and we are grateful. ${ }^{23}$

\section{"TomboAti" anxiety medicine liver and heart as a valuable asset}

Suluk contents Katentraman Soul

"TomboAtiKaryaSunanBonang"

Tomboatiiku lima ingwernane Kapingpisanmaca Qur'an sakma'nane Kapingpindho, sholatwengilakonono Kapingtelu, wongkangsholehkumpulana Kapingpapat, wetengiroingkangluwe Kaping lima, dzikirwengiingkangsuwe Salah sakwijinesapa bias nglakoni Insya Allah GustiPangeranngijabahi

Translation:

Heart medicine there are five things The first read the Koran and plumbed the meaning The second night prayer steadfast

The third one assembled by righteous The fourth fasted

The fifth lingering remembrance night 24 Anyone who can run pray Hopefully one of them will be granted

\footnotetext{
${ }^{23}$ HaqZaairul, SulukKatentraman Soul SunanBonang ... h. 63

${ }^{24}$ HaqZaairul, SulukKatentraman Soul SunanBonang ... h. 4
} 
TomboAti hum is certainly not foreign to our ears. Often we hear this hum sung by religious singers like Opick, emhaainunnadjib (Cak Nun) by Kyai Kanjeng her, and so forth. ${ }^{25}$ Even in many mosques, prayer room, and broken in the countryside too, humming TomboAti still often sung as a form of praise in prayer Iqama wait. About the history of TomboAti, it is said that it was composed by SunanBonang, who lived around the year 1465 up to $1525 \mathrm{AD}$. Aside from being a comforter in times of loneliness, songs TomboAti could also provide a valuable lesson to us all. So what lessons can we learn from it? Let us refer to the discussion on this matter.

To begin this discussion, at least we should ask first, what exactly is the heart? In various studies that have been done by the scholars' "heart" or Al Qolb has two meanings:

1. Al-Qalb with the physical sense, it is a piece of meat elliptic located on the left chest, which is medically he has certain functions that are useful for the survival of every human being. ${ }^{26}$

2. Al-Qalb with heart in the sense of understanding as subtle unseen divine and the sensory and spiritual, but still nothing to do with the heart in the sense of physical earlier.

\footnotetext{
${ }^{25}$ HaqZaairul, SulukKatentraman Soul SunanBonang ... h. 4

${ }^{26}$ HaqZaairul, SulukKatentraman Soul SunanBonang ... h. 5
}

In this discussion, liver or al-qalb in the sense that the latter is to be well served. It has been reported, that the heart there are four kinds:

a. A clean heart, in which bright as the lights, this is the heart of a believer.

b. Closed-hearted and binds to its closure, that the hearts of the unbelievers.

c. Hearts are prone that the heart of a hypocrite

d. Hearts are layered, in it there is faith and hypocrisy.

HujjatulMukhtasar Islam Imam Ghazali in Ihya " Ulumuddin explained ${ }^{27}$, That the heart has two meanings:

1. Meat-shaped pine trees located on the left chest. In it there is a cavity that contains a black blood. This is the source of the spirit.

2. Luth spiritual Rabbani, Which has links with this meat. Rabbani Luthf is to know Allah. He knew that was not achieved figment of the mind. He is human nature. Here's one to talk. Against this meaning is indicated by the word of Allah:

\footnotetext{
${ }^{27}$ HaqZaairul, SulukKatentraman Soul SunanBonang ... h. 5
} 
"Verily in this is there really a warning to those who have the intellect or the use of his hearing, while he watched." (QS. Qaf 50/37).

Hearts in meaning as something subtle and divine, then it has a significant potential which, if managed properly will give a very great impact for human beings. Because he will be able to easily receive the divine energy in the form of the power of faith. But he would be very dangerous if people no longer notice it. Therefore, when the heart is never cared, he would be dirty, hardened, and moss. ${ }^{28}$ Moss is what will be the hijab obstacle in accepting every truth that comes from God. ${ }^{29}$

Let us refer to the words of the prophet the following:

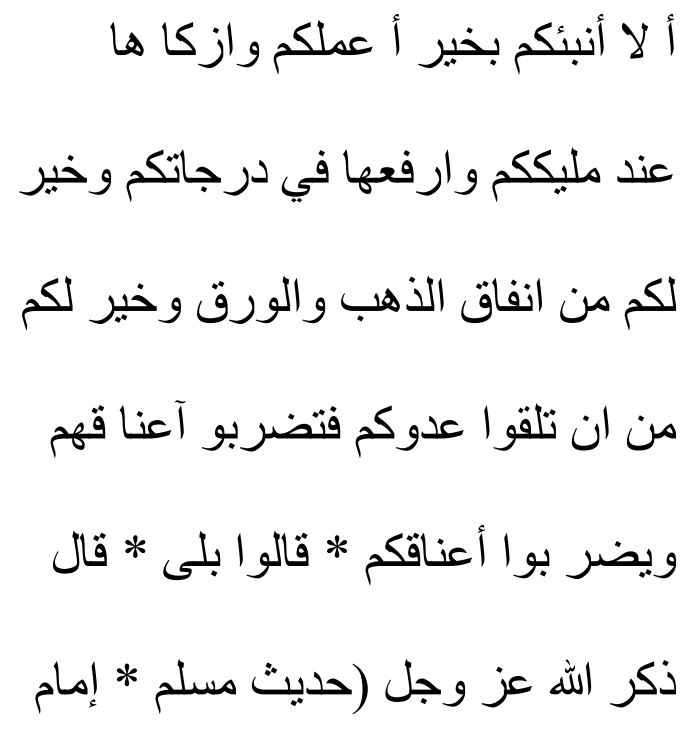

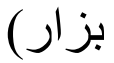

"In the presence of the Prophet, the Prophet once said," would you all I tell about the deeds of the most beautiful and the most clean before God to be king you, also the charity of the most highest rank, which is better than nafaqah gold and silver , which is better than thou jihad fighting the enemies of God that causes you cut off their heads or cut your throat? "then, replied the friend," well, charity if it was, yes prophet? "the prophet," Dzikrullah: remembering Allah 'Azza wa jalla . "30

Shaikh Musleh once quoted sermon by Sheikh Ali al-murshifi, that of the as-Saniyah Minah book, which reads: "In fact, the great teacher can be difficult to give medication to students-santrinya that emit their hearts, except with dhikr mendawwamah. Thus, dhikr like "millstone" that is useful to polish copper due to the benefits of dhikr can illuminate the heart. While deeds besides dhikr like a dab of soap alone: still difficult to use to clean the rust. ${ }^{31}$ Word of the prophet:

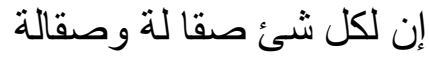

القلوب ذكر الله

"Inasmuch as no cleaner. Liver cleanser is being recollection of God ".

Hearts as a valuable asset

How precious is the heart so that the world should pay attention salikThoriqoh a Shari'ah

\footnotetext{
${ }^{30}$ Murtadho H. Hadi, Three Land Sufi Master Java (Yogyakarta: LKiS-library Pesanteren) h.226

${ }^{31}$ Murtadho H. Hadi, Three Sufi Master Java Land ... h 227
} 
seriously as well as deeds Qolbi (heart) any serious attention. Thus it Thoriqoh

Abuya said Dimyati: ولها ثلاث صفات:

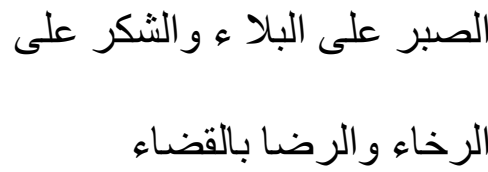

"This Thariqoh has three properties, namely: 1). Patience when misfortune befalls; 2) I'm glad when it gets spaciousness, and 3) Ridho against the "decision" of God.

In Thoriqoh, patience and gratitude is not the nature, but rather categorized into the station and ahwal (deeds liver). Therefore, the real question is AbuyaDimyati, a students serious in nature taking thoriqoh should have patience, gratitude, and blessing. Patience and gratitude as keeping the currency two are inseparable. A slave can be patient if he's gratitude, and to say thanks if he patiently. Therefore, including the wisdom - divine is that in every ni'mat while a slave is still the world is always hidden "catastrophic" and "test". ${ }^{32}$ Thus, if a slave does not "wait" received test form this favor, he could fall into "Kufr ni'mat"33,

Athailah Imam Ahmad has said in his book:

Light is the army of the liver, as well as the darkness into armies of lust. If Allah wills helped his servant, He spread the light that will be the army of

\footnotetext{
${ }^{32}$ Murtadho H. Hadi, Three Sufi Master Java Land ... h 78
}

${ }^{33}$ Murtadho H. Hadi, Three Sufi Master Java Land ... h 77 the liver, and his severed relationships that will help armies of lust by darkness.

Explanation of Qoyyim and Imam Ahmad Ibn Athailah above provide important lessons for us, ${ }^{34}$ that in humans there are several important potential in the form of hidden strengths. These potentials are directly related to the quality keshalihan man in her life, which if managed in the best possible personal contrivances that deserves to be called a "man of God". In this context, the meaning of "servant" not only as beings who simply have an early awareness of the existence of God and provide a mirror of faith that worship is born alone, but further than that, meaning "servant" in the context of this time is a believer who has deceived the potential importance of human beings, namely: physical potential, the potential of sense, and the most important is the potential for liver ${ }^{35}$,

Therefore, every human being, however, he was, in any profession, should be able to manage one of its important potential, which is the heart of a (heart). Especially for a servant who claims to believe in Allah, the most valuable asset of this should really be guarded, nurtured and fed a diet "nutrition" useful. A servant is smart, he will soon find out that the heart has actually has two powers, which if managed well then he will have a heart that

\footnotetext{
${ }^{34}$ Zaairulhaq, Suluk Peace Soul SunanBonang ... h 37

${ }^{35}$ Zaairulhaq, Suluk Peace Soul SunanBonang, (Bantul: Media Insani) h 38
} 
is of quality. ${ }^{36}$ Two strengths are: first, the power of science and differentiator. Second, the power of desire and love. Ibn Qayyim has explained that "perfection and kindness can be achieved by using two such powers to the things that are beneficial to her, as well as for the good and happiness in accordance with the path that has been outlined by religion.

Then Shaykh Dimyati once said, "The doctors in our time is very little." That, stated in his treatise, entitled Hadiyyah al Jalaliyah. Of course, the intention is not AbuyaDimyati physical health doctor, but the doctor spiritual. Furthermore, DimyatiAbuya message, "Let the slave (students) run as far away from the place -the leading to defamation of religion." Because of places like it is "regional disease" growing pain for the liver, as well as body conceded toxic or rotten food. The pain of the heart is always cause prolonged pain (and Hereafter). ${ }^{37}$

The following message AbuyaDimyati pleased with the foregoing: ${ }^{38}$

$$
\begin{aligned}
& \text { (ولها شرط) وهو ان يهرب } \\
& \text { بنفسه من مو اضع التهمة اكثر مما يخا } \\
& \text { ف من وجود الألم, فان مو اضع التهمة } \\
& \text { توجب السقم على القلب كما توجب }
\end{aligned}
$$

\footnotetext{
${ }^{36}$ Zaairulhaq, Suluk Peace Soul SunanBonang ... h 42

${ }^{37}$ Murtadho H. Hadi, Three Sufi land of Java ... h. 82

${ }^{38}$ Murtadho H. Hadi, Three Sufi land of Java ... h. 83
}

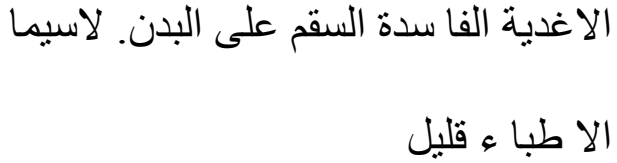

"Thoriqoh setting the terms (for students follower thariqoh), which is as follows: a pupil facer thariqoh let distanced itself from the" slander region "as far away as fear of the students at the pain caused by it. Because, "slander region" is in fact the usual cause suffering to the heart, as the pain of the body because the food was rotten. Moreover, the "doctor" in the present is very little ".

\section{Heart pain}

Similarly, as the human body, there is a healthy body, illness, disability, and death. A healthy liver, as has been explained very simply, it is a very valuable asset, because with a healthy heart the whole body will always do things that are healthy in the sense that according to religious rules. He will be a servant who always sought to draw closer to God, in order to meet the call to be cautious. However, there is also a sick heart, the living heart, but he had a disability. Ibn al-Qayyim said,

That the diseased liver is the liver that circumvents the original creation, ie the team to know God, love Him, wanted to meet him, go back to 
him and put it on all lust semuannya. Suppose a servant knows everything, but he does not know God, it is as if he did not know anything. If he gets all the world, the enjoyment and syahwatnya, but do not have love for Him, as if he did not get the delicacy, enjoyment, and conditioning the heart altogether. ${ }^{39}$

As an explanation of Ibn Qayyim, that the diseased liver is the liver that still keep the two love, that love for God and for lust. In diseased liver, it is often a fight between good and evil. As if deep down inside that there are two people who always try to influence it. The first appeals to the goodness, while the latter called on to perform immoral acts. So sometimes diseased liver was tempted to meet the call of the second caller, there are times when he summons the second caller, sometimes he summons the first caller. Thus, this is a test for the liver to prove his faith in God.

First, a healthy liver and survived, the heart always accept, love and put the truth. His knowledge of the truth is absolutely perfect, always obedient and fully accepted. He will menjadin impregnable fortress, which is always resistant to raids, and he will continue to prevent the entry of immorality and corruption in his heart, and membentenginya with acts of worship to God.

Second, a hard heart, that heart that did not receive and obey the truth. Third, the

\footnotetext{
${ }^{39}$ Zaairulhaq, Suluk Peace Soul SunanBonang ... h. 44
}

heart is sick, if the disease was relapsed then his heart becomes hard and die, and if he beats his heart disease then his heart to be healthy and happy. A diseased liver is often seized with negligence in the remembrance of Allah. In fact, sometimes he had trouble remembering Allah, because a lot of worldly temptations are not able to refuse. He was always interested in worldly pleasures, and not realize that little by little he lapsed into apostasy valley. He was in pain, but did not feel the pain, because the earthly cradle has given anesthetic that makes the heart become "unconscious". In the unconscious, he often interpret worldly tranquility as essential tranquility that had been ordered to hunt. $\mathrm{He}$ is like a lamp whose light looks dim, because it is full of dirt that enveloped him.

Therefore, the diseased liver should be immediately treated with heart medications (Tombo Ati), so he would not be dead. Because when the heart is dead, there is no medicine that can heal, but the guidance of God. Therefore, the heart has to die so he can no longer distinguish between good and evil $^{40}$.

\section{Hearts that have died}

Shaykh Muhammad has said in his explanation of the book al-hikam, that everything that exists in

\footnotetext{
${ }^{40}$ Zaairulhaq, Suluk Peace Soul SunanBonang ... h. 52
} 
this world is actually completely dark. While giving light to dark was God. Anyone who has seen a manifestation of God in the universe, but he has not witnessed al-Haq was within this universe, or to himself, or earlier or later (either microcosm or in macrocosm), then surely the light that has menyilaukannya, so that the landscape makrifat unobstructed rays because of fog around it.

This description shows that the human heart adrift in worldly pleasures, then it means it has been entered into the dark abyss that is very dense, there is no light at all in it. If he really has been in and enveloped by all the darkness, then he would be a dead heart, which is no longer able to digest the truth as something that is needed, and even he is not willing to accept the truth as true. She will be consumed by lust, and he will be a slave to the accursed devil.

Dead heart is a heart that really have been away from the faith. He was too far away from the light of faith, until he got lost in the valley of darkness, for there is no iota of light to give instructions to him. Like a person walking in the pitch-dark night with no light at all bobbing aimlessly, as well as with those whose hearts are dead. Even more than that, he not only cast adrift, but he also felt that it was a true pleasure. ${ }^{41}$ Thus, "Allah has sealed their hearts and their hearing, and their eyes closed. And for them is a great punishment."

\footnotetext{
${ }^{41}$ Zaairulhaq, Suluk Peace Soul
} SunanBonang ... h 53
Stated by Ibn Jarir and Ibn Ishaq Muhammad ibn Ikrimah, from Said bin Jabir, from Ibn Abbas, that the two paragraphs above down on the Jews in Medina. ${ }^{42}$

Disbelievers in the paragraph above are the ones that cover the signs of God and the truth that lay very clearly in this universe, who could not believe in Allah caused their hearts are really dead. "Same thing for them", given a warning or not, they still would not be willing to accept Islam as the true religion. This clearly and firmly say, that the heart that has died really have sunk to darkness, so it can not accept the truth again.

\section{Liver disease}

City park guards often put up a banner that read: "Clean is beautiful!" Not much different, teachers thariqoh was always trying to keep the garden is breathtaking. For them, purity, clean, pure (tajid) is a way of life. Shaikh Dimyathi order:

$$
\text { و و ولها طها رة با طنة وهي من الحرص و الحقد و الكبر ونحو ها وظاهرة }
$$

"In Thariqah, clean very stressed. Net inward ie net of liver diseases such as greed, hasud, "their emotions have been expressed", pompous and the like. And also clean dzahir, remember the message of Personality 'about the cleanliness of the body, clothing, and shelter ".43

\footnotetext{
${ }^{42}$ Zaairulhaq, Suluk Peace Soul SunanBonang ... h 54

${ }^{43}$ Murtadho H. Hadi, Three Sufi Master Java Land ... h 80
} 
The human heart must have felt sick, considering they are creatures who can not be free (infallible) from sin and error. Thus, it is every man should keep his heart health of all properties that can make it dark and sick. To that end, it is necessary to understand the various kinds of heart disease, to be treated early, before it makes the heart disease death. ${ }^{4}{ }^{4}$ Because the diseased liver still has a chance to recover, while the hearts of the dead no longer have the opportunity to cure, but only with the guidance of God. Similarly, it is very fortunate people who can figure out any liver disease who are in him, and immediately give the medicine to heal the pain. Instead, it lost the person who is unable to detect any disease suffered by her and she was not immediately aware of it.

\section{REFERENCES}

Achmadi, Ideologies Islamic Education: Theoretical Paradigms Humanism, Yogyakarta, Reader Student 2005

Ahmadi, "Islam as a Paradigm of Educational Sciences", in Isma'il SM, eds, Islamic Education Paradigm, Yogyakarta: Student Library and FakultasTarbiyah IAIN Walisongo 2001

Abrasy, Athiyah Muhammad, Al-Tarbiyah AlIslamiyah, Damascus, Dar Al-Fikr, tth

Arikunto, Suharsimi, Research Approach A Practical Approach, Jakarta: Rineka Copyright 2002

${ }^{44}$ Zaairulhaq, Suluk Peace Soul

SunanBonang ... h. 29
US, Asmaran, Introduction to the Study of Behavior, (Jakarta, PT. King Grafindo), 1994

D. Marimba, Ahmad, Introduction to the Philosophy of Islamic Education, (Bandung, Al-Ma'arif, 1989)

Danim, Sudarwan, Become Qualitative Researcher, Bandung: Pustaka Setia 2002

Daradjat, Zakiah, IImuPendidikan Islam, Jakarta: BumiAksara, 2000

Hadi, Murtadho, Three Land Sufi Master Java (Yogyakarta: LKIS-pustakaPesanteren) 2012

Haq, Zaairul, SulukKatentraman Soul SunanBonang, Bantul: Media Insani 2012

Ghazali, Imam, Miracle Hearts trans. Haidar Bagir, (Bandung, Mizan, 2001)

Ghazali, Imam, Chemicals happiness trans Haidar Bagir, (Bandung: Mizan, 1989)

Judjito, Ahmad, "Philosophy of Values in Islam", ChabibThoha et al. Eds, ReformulasiFilsafat Islamic Education, Yogyakarta: PustakaPelajar, 1996

Kasri Muhammad, khafid, et al, Fiber Daze Dewa Ruci and SulukSunanKalijaga (Sheikh Melaya) Jakarta: BalaiPustaka, 1993. (Manuscript transliteration into Latin letters) and translation into Indonesian)

Langgulung, Hasan, principle - the principle of Islamic Education, Jakarta: Pustaka Al Husna, 1992

Muammar, Siddiq, Privileged Prophet Khidr. (Yogyakarta: SinarKejora, 2012) 
Muslim, Imam Abu Al-Husaian Al-Hajjaj Ibn An- Toha, Chabib, Capita Selecta Islamic Education, NaisabuiriQusyairy, ShahihMuslim, Volume I, $\quad$ (Yogyakarta, PustakaPelajar, 1996)

(Baerut: Da al-FikrKitab Al-natural, 1994) Taomy Omar, Syaibany, FilsafatPendidikan Islam,

Nahlawi Abdurrahman, Usul al-Tarbiyahwaasalibuha trans. Hasan Langgulung (Jakarta: BulanBintang, fi al-Islamiya al-Bayt al-Madrasa wawa al- 1976)

Mujtana'(Damascus, Dar al-Fikr, 1979)

Rahimsyah, AR, MB, Kisahwalisongo, Surabaya:

Ciptakarya 2011 